\title{
ESCLARECIMENTO E OFUSCAÇÃO: ADORNO \& HORKHEIMER HOJE
}

GABRIEL COHN

Meio século após a publicação da Dialética do Esclarecimento, cabe repetir a pergunta sobre o que Adorno e Horkheimer têm a nos dizer hoje nesse seu clássico empreendimento conjunto ${ }^{1}$. Mas, em se tratando de "fragmentos", como os próprios autores descrevem a sua obra, convém ficar também no fragmentário e não tentar juntar tudo à força. Minha referência para isso será a parte dedicada aos "Elementos do anti-semitismo. Limites do Esclarecimento"2; a última delas (se descontarmos as "anotações e projetos" finais) e, numa certa medida, a mais radical. Pois nela não se trata mais, como no restante da obra, de expor o conceito de Esclarecimento, ou de mostrá-lo em andamento em algumas das suas figuras mais características, como na razão esclarecida na forma da moral burguesa ou na cultura como indústria (a versão burguesa tardia da sabedoria como astúcia em Ulisses), mas de expor os seus limites. Vale dizer, tratase de dar conteúdo historicamente específico à crítica.

\footnotetext{
${ }^{1}$ Horkheimer, Max und Theodor W. Adorno. Dialektik der Aufklärung. Amsterdam, Querido Verlag N.V., 1947. (O nome dessa editora deveria ter o seu encanto para Theodor Wiesengrund, que se recusara a dispensar o veneziano sobrenome materno Adorno e pela vida afora reduziria os "prados" paternos a um pálido W.). No Brasil esta obra está disponível (com a interessante solução do termo "esclarecimento" ao invés de "iluminismo" ou "ilustração" para Aufklärung) na tradução do filósofo Guido de Almeida, Dialética do Esclarecimento, Rio, Zahar. (Citada neste texto como $D E$ ).

2 Este artigo tem como base uma exposição feita em 24 de setembro de 1997 no Instituto Goethe de São Paulo, no seminário promovido pelo Instituto junto com a UNICAMP, a PUC/SP e a UFMG e organizado por Jeanne-Marie Gagnebin, Marcos Lutz Müller e Oswaldo Giacóia Júnior, sobre "Os cinqüenta anos da Dialética do Esclarecimento de Adorno e Horkheimer". Agradeço ao Instituto Goethe e especialmente aos organizadores a oportunidade desse debate.
} 


\section{A CRÍTICA RACIONAL DA RAZÃo}

Conhece-se bem o que está em jogo no conjunto da obra. Tratase de um primeiro esforço de aproximação daquilo que se anunciava como uma tarefa de proporções indefinidas, talvez intrinsecamente inesgotável (dado o seu caráter não sistemático e não apenas formal): nada menos do que uma versão contemporânea da crítica racional da razão. Só que agora o pano de fundo não é dado por uma razão dogmática cujos limites formais se trata de estabelecer, como para Kant (este interlocutor fundamental, que ambos os autores, por caminhos diferentes, viam com uma mescla de respeito e reserva) mas pela decomposição da antes orgulhosamente unitária e universal razão burguesa e pelo avanço do irracionalismo, cujos limites materiais se trata de superar. Após Hegel e sobretudo após Marx esse empreendimento tem que ter em vista conteúdos históricos $-\mathrm{e}$, conforme a grande aspiração de Horkheimer, deve fazer parte de uma exposição da dialética. Deve portanto interrogar a razão respeitando todas as suas exigências intrínsecas, sem no entanto perder de vista que, sob a capa da razão sem mais, efetivamente está em cena a sua forma historicamente dominante, a razão burguesa. O procedimento básico adotado, aqui e em outros lugares, foi enunciado em várias oportunidades por Adorno. Tratase de confrontar o objeto com o seu conceito, e cobrar dele a realização de tudo o que está contido neste. Isto permite, desde logo, assinalar os limites da efetivação do conceito na forma histórica que assume e na qual se apresenta como se estivesse realizado. O uso do termo Esclarecimento busca dar conta dessa relação complexa. Não se trata nem da razão sem mais nem da sua redução a uma classe particular, por mais dominante que seja. No mínimo trata-se de olhar a contrapelo, vendo a particularidade histórica na razão que se apresenta como universal sem mais, e vendo a possibilidade da razão plena na sua efetivação restrita ao âmbito de uma classe. Nesta perspectiva o termo não se limita a qualificar uma circunstância dada, ou um período histórico, nem muito menos o ponto alto de um progresso da razão. Designa o próprio processo de constituição e de expansão da razão tal como a conhecemos (pelo menos para quem pensa a partir da Europa). E, nessa sua referência às luzes, a razão esclarecida é sujeita a uma crítica que busca acompanhar a sua trajetória mediante a demonstração, em cada passo, de que ela poderia ser diferente, e que se esforça por perceber as suas tendências internas e os seus limites.

Limites. Como entender esse termo, quando aplicado à figura dominante da razão, em nome da própria razão? Certamente não se trata de 
circunscrever o âmbito da razão, defini-la de alguma forma. Sobretudo, não se trata de sair dela. A crítica, lembraria Adorno, para ter conteúdo e portanto poder aspirar à verdade tem que ser imanente ao seu objeto. Ainda mais nesse caso, da exposição racional do processo histórico naturalizado da própria razão. Pois importa justamente mostrar que ela não pode abrir mão da reflexão sobre si mesma mas que, para fazê-lo, muito menos pode ser desmembrada em "objeto" e em "instrumento" da crítica, e sim deve refletir-se como unidade em ambas essas dimensões. Dadas essas exigências, cabe esperar que os limites da razão esclarecida sejam expostos naqueles momentos do seu processo em que ela, longe de progredir numa espécie de reprodução ampliada de si própria, passa a produzir o seu contrário. Produzir então o mito, que, de acordo com a tese da Dialética do Esclarecimento, insiste em habitar uma razão esclarecida que supõe tê-lo extirpado mas não consegue ir além de reprimi-lo? Não é bem isto, e certamente não é só isto. O mito é com certeza o obstáculo insuperado por uma razão que se tem por esclarecida precisamente em nome dessa superação. Mas o mito já está lá desde o início, é mais a presença que a razão esclarecida não pode admitir do que o seu produto. $O$ mito tem mais a ver com o recuo (mais exatamente, com o medo do recuo) da razão. Tem a ver com sua face defensiva, terrível certamente, mas não mais do que sua face ofensiva levada ao limite.

Ao discutir o anti-semitismo, Adorno e Horkheimer (aqui cabe especialmente a inversão da ordem editorial dos autores, pois o texto exibe em passagens decisivas o inconfundível estilo adorniano) explicitam melhor o que vem a ser esse limite. E o fazem ao expor o que seria na fase contemporânea a contrapartida, no processo da razão esclarecida, à grande oposição que mostraram ao construir o conceito de Esclarecimento: aquela entre razão e mito, que tem como substrato material o projeto de completa dominação da natureza. Trata-se neste ponto de expor uma outra dialética, não a que envolve a razão a e sua sombra mas a que envolve a produção da sua sombra própria pela razão: a dialética da razão e do ofuscamento. Pois nesse texto já ocupa posição central um dos grandes temas de Adorno, que se traduziria na sua concepção de um "nexo universal de ofuscamento": o de que a razão privada da sua capacidade reflexiva, deixada solta na exacerbação do seu impulso dominador alimentado pela sempre presente ameaça da regressão mítica, gera luzes, sim, mas que ofuscam e levam à cegueira. Precisamente nessa relação intrínseca que se estabelece entre luzes e ofuscação consiste o limite da razão esclarecida; e o antisemitismo se apresentava como a figura histórica mais acabada disso. Mas, atenção: não estamos lidando com pensadores convencionais, preo- 
cupados unicamente com afirmar firmemente um estado de coisas e depois sustentar o que foi posto como dado. Se o anti-semitismo entra para caracterizar limites do Esclarecimento num texto com a assinatura de Adorno, há bons motivos para suspeitar que ele acabará revelando sua importância mais pelas tendências que assinala, e que acabam por suprimi-lo na forma particular que exibe, do que pela sua reafirmação como dado persistente da realidade. O problema do texto não se limita ao anti-semitismo como forma local de uma razão fora do eixo mas envolve a sua incorporação num processo mais amplo, em que desaparece como ódio específico aos judeus para integrar novas formas de ofuscação.

\section{ELEMENTOS DO ANTI-SEMITISMO}

No que consiste, afinal, o anti-semitismo, na perspectiva em que se colocam os autores? O modo de comportamento anti-semita é desencadeado em situações nas quais "indivíduos ofuscados e privados da sua subjetividade se vêem à solta como sujeitos"3, escrevem eles em passagem fundamental. Aqui temos reunidos três termos do problema armado pelos autores: a ofuscação, a condição de indivíduos serem privados da sua subjetividade e mesmo assim serem levados a agir como se fossem sujeitos, e este outro termo central no argumento, que é o estar posto "à solta". É este conjunto de questões que cabe agora examinar, para atingir o ponto em que o texto vincula os limites do anti-semitismo, como forma historica e como modalidade de conduta, aos limites da razão esclarecida, na qual ele não é um corpo estranho, como muitos imaginavam, mas exprime algo do que ela tem de mais fundo. Discutir isso envolve também, no mínimo, ter em conta o modo como os autores (especialmente Adorno) vinculam a forma histórica ao comportamento individual. Sobre este ponto cabe assinalar desde logo uma noção que aparece naquilo que era, em 1944, a seção final do texto (uma nova seção final, especialmente desconcertante como veremos, foi acrescentada mais tarde, para a publicação em 1947). Trata-se da idéia de "sociedade anti-semita", referente a uma organização social que gera simultaneamente o anti-semita algoz, o judeu vítima e as

${ }^{3} D E$, p. 160. Nesta passagem a tradução foi modificada, especialmente na substituição do termo "obcecados", que nela traduz o alemão verblendete, por "ofuscados", dado que isto me parece ser de importância central no argumento dos autores. 
formas de conduta que sustentam a patológica cumplicidade entre ambos (na medida em que ambos são igualmente ofuscados, mas certamente não no sentido de que às vítimas caiba culpa). Numa passagem que evoca os debates de exatos cem anos antes na "esquerda hegeliana", eles afirmam que só libertando-se o pensamento da sua fixação na dominação e eliminando-se a violência "seria possível realizar a idéia que até agora permaneceu uma inverdade, a saber, que o judeu é um ser humano. Isto representaria a passagem da sociedade anti-semita, que impele os judeus e os demais para uma condição patológica, para a sociedade humana. (...) Superando a doença do espírito que grassa no terreno da auto-afirmação imune à reflexão, a humanidade deixaria de ser a contra-raça universal para se tornar a espécie que, embora natureza, é mais do que simples natureza, na medida em que se apercebe de sua própria imagem" $(D E, 186)$.

Antes de entrar no corpo dos problemas, cabe uma observação sobre a referência dos autores a "elementos" do anti-semitismo. Até que ponto é importante este específico termo na formulação do seu tema? No prefácio ao livro os próprios autores sugerem uma explicação simples. É que esse texto é construído na forma de "teses" e não de algo como uma exposição sistemática e amarrada do tema. É verdade que essa forma de exposição por teses seria mais tarde adotada várias vezes por Adorno, em artigos dedicados a "teses sobre o cinema", por exemplo. A alusão, nesse caso, é a algo sumário, a aperçus, para usar o francês com que nos seus textos impecáveis Adorno lembrava os puristas tedescos de que existe civilização para além da terra de Goethe. Um passo a mais tornaria explícita a referência à forma do ensaio, tão apreciada por ambos. Entretanto, eu me aventuraria a sugerir que a coisa vai mais fundo. Isso se revela naquilo que passou a ser a nova seção final do texto publicado em 1947. Essa seção, que à primeira vista é uma espécie de afterthought, introduz um tema novo, que deriva das pesquisas de que Adorno participou nos mesmos anos em que trabalhava com Horkheimer na redação da Dialética do Esclarecimento (e, nesta nova seção, também com Leo Löwenthal). Este novo tema, e o próprio problema formulado nessa seção (que serão discutidos mais à frente) praticamente reorganizam o conjunto, e permitem repensar a questão dos "elementos". Antecipando minha posição a respeito, eu diria que não é de todo um abuso em relação ao texto se ele for lido como se o termo "elementos" dissesse respeito, não às partes de um sistema (o que certamente não é o caso) nem meramente a uma vista de olhos fragmentária sobre um grande tema, mas a um processo de decomposição de um objeto (com o que se acaba aludindo a outro dos grandes temas de 
Adorno). Ainda que fale do anti-semitismo de modo muito preciso ao caracterizá-lo nos seus traços distintivos, a análise, ao fazê-lo, vai apontando para um processo subjacente. Trata-se da sua redução a elementos que, se ainda são do anti-semitismo, assinalam contudo a gradativa redefinição do complexo anti-semita como um todo, no interior de um processo que o prolonga e supera. Em suma, convém ler o texto de modo a impedir que uma passagem rápida demais da idéia de elementos do anti-semitismo para a idéia de teses sobre o anti-semitismo esconda os problemas que aquela formulação suscita.

\section{OS SUJEITOS OFUSCADOS}

Comecemos pela questão do sujeito. Esta questão é central para os autores no seu tratamento da razão esclarecida, e não poderia deixar de estar no centro do exame dos seus limites. Um traço central da dialética exposta é que nela a primazia, que aparentemente é do momento subjetivo da razão como dominante, passa para o momento objetivo, pois é na referência externa a ele que se concentra todo o esforço de auto-preservação do sujeito. A razão esclarecida contenta-se com o domínio sobre o objeto, seja ele qual for. O poder que ela confere ao sujeito consiste justamente na faculdade de definir o objeto e manter-se a prudente distância dele, sem envolvimento, sem o movimento da reflexão que envolve sujeito e objeto num processo solidário. Mas nisso empobrece-se a condição de sujeito e perdese o compromisso inerente à razão plena, e esquecido pela razão esclarecida: o da razão consigo própria, mediante a reflexão no sujeito. Para um sujeito pleno de uma razão também plena, que não se limitasse a projetar luzes, não haveria um corte entre sua diferença e sua semelhança relativamente ao objeto. Pois é na conjugação de ambas sem reduzir uma à outra que consistiria a sua própria atividade enquanto sujeito. Neste sentido a atividade do sujeito estaria voltada mais para o aproximar-se e o assemelhar-se do que para o afastar-se e o distinguir-se: seria mais da ordem da mimese do que da dominação. Esta plenitude do sujeito e da razão é uma possibilidade inerente à propria configuração humana nas suas relaçōes com a natureza, à sua "antropologia" como diria Horkheimer. Mas o que se realiza aqui e agora é diferente. Para o sujeito empobrecido da razão esclarecida o objeto tende a reduzir-se a uma alteridade, ao outro opaco. No seu limite, na conduta anti-semita, não há sujeitos verdadeiros, porque não há reflexão que permita ao sujeito "devolver ao objeto aquilo que dele recebeu" ( $D E$, 
176). Há ações irrefletidas de pseudo-sujeitos que, como tais, só podem ver no objeto a coisa estranha, em relação à qual a semelhança só pode ser escárnio. Quando, nessas condições, lhe são conferidos atributos do sujeito - discernimento, escolha, decisão - seu olhar fixo concentra-se no seu objeto como o outro absoluto, simultaneamente ameaça e presa, e sua ação incide sobre o traço do outro que o defina, a idiossincrasia que permita mantê-lo em foco, que possa ser exibida na representação que dela se faça. Se o outro é o judeu seus traços idiossincráticos serão fixados na gesticulação, na voz, na forma do nariz. "A energia psíquica mobilizada pelo anti-semitismo político é essa idiossincrasia racionalizada" ( $D E, 171)$.

Mas não é só o outro que é desqualificado nesse gesto. A própria imitação rancorosa dos traços do outro evoca, ainda que de modo deformado, a semelhança que vem da aproximação e não da repulsa, o gesto mimético do sujeito que se aconchega ao objeto, a razão que se realiza ao amoldar-se à natureza e não ao mantê-la à distância, subjugada. Ao atingir o seu limite, no olhar opaco do pseudo-sujeito desatado do compromisso racional com a reflexão, a razão esclarecida produz, na conduta anti-semita, a mimese disforme da mimese verdadeira: daquela aproximação reflexiva em que a razão, pela via do sujeito, não se limita a iluminar o seu objeto mas conforma-se a ele. A semelhança deformada reitera ao seu modo a outra semelhança, a mimese da razão na sua plenitude possível, quando ela não se detém diante da sombra do mito nem produz a ofuscação, mas propicia aos sujeitos a capacidade de manter os olhos abertos e sobretudo móveis (pois a ofuscação de que aqui se fala não é tanto a cegueira quanto a paralisia do olhar, atento mas fixo num só ponto). A mimese da razão plena não é homogeneizadora. Não se trata de universalizar a semelhança, mas de achegar-se reflexivamente ao diferente. É isto que é radicalmente vedado ao comportamento anti-semita. E esta radical incapacidade sinaliza o limite da razão esclarecida, o ponto a partir do qual ela ou se supera na figura de uma razão mais diferenciada ou então volta obstinadamente ao seu princípio fundante, que é o da autoconservação. Mas isto implica reiterar, sob outras formas e em escala diferente, aquilo de que o anti-semitismo é a expressão mais pungente.

\section{A PERSONALIDADE AUTORITÁRIA}

Mas a nova seção final introduz uma afirmação desconcertante. "Não há mais anti-semitas", afirmam os autores (DE, 183). 
Estaríamos diante de um mero lance de ironia, talvez com referência à Alemanha após a guerra, quando os nazistas e os anti-semitas se evaporaram como por encanto? Se fosse só isso seria difícil justificar a posição, que afinal também é a adotada neste artigo, de que estamos diante de uma análise de excepcional alcance, que merece tanta atenção hoje quanto há meio século. Convém, portanto, procurar melhor o significado dessa passagem. Para isso um bom caminho consiste em examinar alguns aspectos das contribuições de Adorno à pesquisa coletiva de que participou, sobre a "personalidade autoritária"4. A preparação dessa pesquisa (e de outras, dentro de um projeto maior, centrado no problema do antisemitismo nos EUA, dentro de uma concepção em que este comparece como um elo na relação entre autoritarismo e fascismo) coincidiu em grande parte com a redação da Dialética do Esclarecimento, e sua realização final ocorreu no período final da guerra e no imediato pós-guerra. Da perspectiva de Horkheimer e Adorno ambos os trabalhos tinham antecedentes no Instituto de Pesquisa Social que o primeiro dirigia, especialmente no amplo estudo dos anos 30 sobre "autoridade e família". Fundamental na pesquisa sobre a personalidade autoritária foi a mobilização do instrumental analítico da psicologia social e da psicanálise, associada a uma concep̧̧ão sociológica do conjunto (a cargo de Adorno), tudo isso voltado para uma associação entre a criação de instrumentos de pesquisa específicos, o rigor no tratamento dos dados e uma orientação geral mais dirigida para a análise qualitativa em profundidade dos dados. Nisso tudo Adorno teve papel importante, a começar pelo seu entusiasmo pela idéia da construção de instrumentos orientados para a captação de traços de personalidade e de padrões de comportamento por via indireta, mediante questionários e entrevistas construídos para atingir motivos não diretamente verbalizáveis pelos sujeitos, associados ao uso criativo de escalas de medida de atitudes. (Não é este o momento para desenvolver isto, mas a principal contribuição de Adorno à pesquisa empírica consiste na valorização dos recursos analíticos que permitam atingir por vias indiretas os condicionantes sociais das atitudes, das ações e das formas de pensamento em contextos determinados). A questão básica a ser examinada era: que traços de personalidade caracterizam o tipo de indivíduo propenso a aceitar formulações e propaganda antidemocrática? (O termo "antide-

${ }^{4}$ Adorno, Th. W., Else Frenkel-Brunswik, Daniel J. Levinson, \& R. Nevitt Sanford. The Authoritarian Personality. New York, Harper \& Row, 1950. Será usada a edição de 1964 da Science Editions (New York, John Willey \& Sons). 
mocrática" é textual, e mostra que o escopo da pesquisa é bastante amplo). O problema de fundo, contudo, era de natureza social e política mais do que psicológica. Como diria Adorno anos depois, na célebre polêmica com Karl Popper sobre a metodologia das ciências sociais: "A sociedade é um processo total, no qual os seres humanos abrangidos, dirigidos e formados pela objetividade mesmo assim retroagem sobre ela (...). Com certeza não se pode explicar o fascismo socio-psicologicamente, como ocasionalmente foi mal interpretada a Authoritarian Personality. Por outro lado, se o caráter preso à autoridade não fosse tão difundido, por motivos discerniveis sociologicamente, então o fascismo não teria encontrado a base de massa sem a qual dificilmente teria chegado ao poder numa sociedade como a da democracia de Weimar." 5

Os esforços de Adorno para projetar a análise da personalidade autoritária sobre um enquadramento que lhe permitisse transcender o plano estritamente socio-psicológico aparecem com nitidez no modo como ele comenta um dos achados da pesquisa: o de que aqueles que se revelavam propensos à aceitação de temas e formas de conduta fascistas tendiam a organizar suas idéias em termos que envolviam simultaneamente o pensamento por estereótipos (conforme padrões fixos previamente dados para qualificar pessoas e coisas) e de modo personificado. A passagem decisiva merece ser citada inteira: "Tanto a estereotipia quanto a personificação são inadequadas à realidade. Sua interpretação pode assim ser vista como um primeiro passo rumo à compreensão do complexo de pensamento 'psicótico' que parece ser uma característica crucial do caráter fascista. É óbvio, contudo, que esse malogro subjetivo na apreensão da realidade não é primária e exclusivamente uma questão da dinâmica psicológica dos indivíduos envolvidos mas é em certa medida devido à própria realidade, à relação ou carência de relação entre essa realidade $\mathrm{e}$ $o$ indivíduo. Na medida em que se esquiva do concreto e se contenta com idéias preconcebidas, rígidas e supergeneralizadas, às quais o indivíduo atribui uma espécie de onipotência mágica, a estereotipia não alcança a realidade. Por seu lado, a personificação esquiva-se da abstração real, vale dizer, da 'reificação' da realidade social, que é determinada por relações de propriedade e na qual os seres humanos figuram como se fossem meros apêndices. A estereotipia e a personificação são duas partes

5 "Sobre a lógica das ciências sociais". in Gabriel Cohn (org) Theodor W. Adorno. Coleção "Grandes Cientistas Sociais", vol. 54. São Paulo. Editora Ática, 1986. 
divergentes de um mundo não experimentado efetivamente, partes que não apenas são irreconciliáveis entre si como também não permitem qualquer adição que reconstruísse o quadro do real". 6

Nesta passagem se vê como Adorno procura instilar na análise dos resultados da pesquisa as concepções teóricas mais abrangentes, que permitissem estender o seu significado até muito além do que uma sociologia ou uma psicologia social convencionais e mesmo um enfoque psicanalítico poderiam atingir por suas próprias forças. Na realidade essa passagem oferece um motivo adicional para o interesse. É que nela Adorno vence (ou esquece) as suas inibições em relação a quaisquer formulações que pudessem soar demasiado marxistas no seu exílio norte-americano. No caso, isto ocorre na referência à "reificação" da realidade social determinada por "relações de propriedade", numa formulação em que são abandonados os eufemismos a que recorre em outros momentos. É verdade que a este respeito é preciso reconhecer que nem sempre se trata meramente de formulações atenuadas em vista das injunções do meio. Adorno jamais assimilou a linguagem mais dura de um marxismo "ortodoxo" como adequada ao tipo de análise que se propunha fazer. Mas aqui, quando estão em jogo as relações entre a realidade social e os indivíduos, a referência ocorre espontaneamente. Isso permite conjugar na análise os temas da experiência, da cognição e da consciência, todos eles num registro negativo no caso. Temos aqui três dimensões de insuficiência que se traduzem numa forma de pensamento com características patológicas, e isto não no plano estritamente individual mas naquilo que se refere às relações entre o indivíduo e a realidade social. Isto resulta em duas orientações opostas do pensamento, em que essas insuficiências ou se traduzem na falta de senso do concreto ou, inversamente, na falta de senso da abstração. Estereotipia e personificação são portanto traços opostos mas simultaneamente presentes em um tipo de caráter propenso a realizar por seu intermédio uma das virtualidades (a atitude antidemocrática) da sociedade que oferece as condições para engendrá-lo. No seu caráter contraditório elas "exprimem o impasse no qual se encontram muitos indivíduos" $(A P, 664)$ e, numa imagem muito expressiva se considerarmos as elaborações na Dialética do Esclarecimento, constituem "técnicas de orientação que, por cruas e falaciosas que sejam, o ajudarão a achar o seu caminho no escuro, por assim dizer" (AP, 663-64). Entretanto, não há como juntá-las para obter um

${ }^{6}$ The Authoritarian Personality, vol. 2, p. 644. 
quadro completo da realidade social em que se exercem, até porque a soma de duas insuficiências não restaura um todo. Falta algo, há um ponto cego nessa relação. E se precisamente nesse ponto cego se instalasse outro tipo de pensamento, que de alguma maneira fechasse esse circuito, ainda que sem resolver as suas insuficiências?

\section{PENSAR EM BLOCO}

É precisamente isto que realiza uma idéia importante apresentada na pesquisa sobre a personalidade autoritária que Adorno trouxe para as reflexões sobre o anti-semitismo na Dialética do Esclarecimento. Trata-se da noção de ticket-thinking. Embora pouco desenvolvida, ela comparece na análise da personalidade autoritária em posição cuja centralidade (no capítulo sobre "política e economia no material das entrevistas", redigido por Adorno) a sua retomada no texto sobre o anti-semitismo na Dialética do Esclarecimento só faz confirmar. Na realidade o ticket-thinking engloba numa unidade a polarização estereotipia /personalização, associando-as numa forma de pensar "em bloco", conforme padrões prontos (daí a alusão, na expressão, a listas partidárias em que um voto carreia apoio a todos os candidatos inscritos à revelia do eleitor). Já nesse ponto Adorno fica devendo uma análise mais funda dessa unidade complexa e problemática que é o ticket-thinking. Trata-se de uma forma de perceber o mundo e de pensar que opera conforme blocos de significados previamente dados, que se apresentam como coerentes para o sujeito (na medida em que aceitar um dos seus elementos leva a aceitar os demais sem esforço de ajuste nem, muito menos, de reflexão) mas que na realidade são intrinsecamente contraditórios (na medida em que associam a estereotipia e a personificação num conjunto que resiste a completar-se).

A importância disso revela-se naquilo que (conforme aqui se sustenta) é uma passagem decisiva na Dialética do Esclarecimento, exatamente quando os autores desenvolvem a afirmação de que "não há mais anti-semitas". Referindo-se ao anti-semitismo no período anterior ao nazismo, eles comentam: "O anti-semitismo ainda era um tema aberto à escolha subjetiva, e a decisão referia-se especificamente a ele". E continuam: "É verdade que a aceitação da tese racista já implica todo o vocabulário chauvinista, e que os juízos anti-semitas deram sempre testemunho de um pensamento estereotipado. Mas, hoje, é só isto que resta. Continua-se a escolher, mas apenas entre totalidades. A psicologia anti-semita foi, em grande parte, 
substituída por um simples 'sim' dado ao ticket fascista, ao inventário de slogans da grande indústria militante" ( $D E, 187)$. Nessas circunstâncias, "a experiência é substituída pelo clichê e a imaginação ativa na experiência pela recepção ávida". Há nisto uma lógica, que deita raízes, para além da política, no modo de organização da produção. "No mundo da produção em série, a estereotipia - que é o seu esquema - substitui o trabalho categorial. O juízo não se apoia mais numa síntese efetivamente realizada, mas numa cega subsunção. (...) Antes, o juízo passava pela etapa da ponderação, que proporcionava certa proteção ao sujeito do juízo contra uma identificação brutal com o predicado. Na sociedade industrial avançada ocorre uma regressão a um modo de efetuação do juízo que se pode dizer desprovido de juízo, do poder de discriminação. (...) Se, no interior da própria lógica, o conceito cai sobre o particular como algo de puramente exterior, com muito mais razão, na sociedade, tudo o que representa a diferença tem que tremer. As etiquetas são coladas: ou se é amigo, ou inimigo. A falta de consideração pelo sujeito torna as coisas fáceis para a administração. Transferem-se grupos étnicos para outras latitudes, enviam-se indivíduos rotulados de judeus para as câmaras de gás" ( $D E, 188)$. E, da sugestiva comparação (bem ao gosto de Horkheimer) da construção psicanalítica do aparato psíquico a uma "pequena empresa interior" que não resiste ao confronto com sociedade organizada conforme o padrão das grandes corporações, obtêm a conclusão de que, junto com o declínio da pequena empresa, "os sujeitos da economia pulsional são expropriados psicologicamente e essa economia é gerida mais racionalmente pela própria sociedade. A decisão que o indivíduo deve tomar em cada situação não precisa mais resultar de uma dolorosa dialética interna da consciência moral, da autoconservação e das pulsões" $(D E, 189)$.

Para fechar o diagnóstico falta somente um passo, naquilo que aqui importa. E esse passo é dado mais adiante, quando se discute a "mentalidade do ticket" como "produto da industrialização e da sua propaganda" num contexto em que "a aparência ficou tão espessa que a possibilidade de devassá-la assumiu o caráter de alucinação. Escolher um ticket, ao contrário, significa adaptar-se a uma aparência petrificada como uma realidade e que se prolonga a perder de vista graças a essa adaptação". E, indo ao ponto: "O senso de realidade, a adaptação ao poder, não é mais o resultado de um processo dialético entre o sujeito e a realidade, mas é imediatamente produzido pela engrenagem da indústria. $O$ processo é de liquidação em vez de superação, é um processo de negação formal em vez de negação determinada. Não foi lhe concedendo a plena satisfação que os 
colossos da produção desatados superaram o indivíduo, mas extinguindo-o como sujeito. É nisso justamente que consiste sua racionalidade consumada, que coincide com sua loucura" $(D E, 191)$. Essa insânia tem sólido fundamento objetivo: "A irracionalidade da adaptação dócil e aplicada à realidade torna-se, para o indivíduo, mais racional do que a razão. Se, outrora, os burgueses introjetavam a coação em si mesmo e nos trabalhadores como um dever de consciência, agora o homem inteiro tornou-se o sujeitoobjeto da repressão. O progresso da sociedade industrial, que supostamente teria eliminado como que por encanto a lei da pauperização que ela própria produzira, acaba por destruir a idéia pela qual o todo se justificava: o homem enquanto pessoa, enquanto portador da razão. A dialética do esclarecimento transforma-se objetivamente na loucura" $(D E, 190) .^{7}$

\section{EXPROPRIAÇÃO E REGRESSÃO}

Claro que o mais importante nessas passagens notáveis, no que tange ao argumento deste artigo, é a referência aos "colossos da produção desatados", que será retomada mais adiante. Mas, feitas as citações, não é possível deixar de também chamar a atenção para o modo como se articulam com o resto. Nelas é possível perceber com especial nitidez o entrelaçamento de modos de pensar característicos de cada um dos autores. Dois temas se cruzam aqui. Um traz mais a marca de Horkheimer, e diz respeito à expropriação, que, sem perder sua forte ressonância marxista, se apresenta para designar uma ampliação historicamente determinada do escopo de processos de natureza estritamente econômica na origem. $O$ outro é o da regressão, e traz a marca de Adorno. Nele se exprime a dúvida quanto à concepção de progresso cultivada pela razão esclarecida e se levanta do modo mais conseqüente (vale dizer, sem qualquer concessão à idéia de "etapas") a questão de um movimento regressivo que se traduz no afastamento, mais exatamente no recuo forçado, em relação ao que seria objetivamente possível alcançar nas condições históricas presentes. Adorno já havia tratado desse tema de uma maneira que antecipa argumentos da Dialética do Esclarecimento no seu ensaio de 1938 sobre "o fetichismo na música e a regressão da audição". Nesse ensaio ele afirmava que os ouvintes "não são infantis (...), mas são pueris. Seu primitivismo

${ }^{7}$ Nesta citação e na anterior foram feitas modificaçōes na tradução. 
não é dos não-desenvolvidos e sim dos empurrados para trás à força. Sempre que thes é possível eles manifestam o contido ódio daqueles que na realidade percebem o diferente mas têm que abster-se dele para poder viver sem perturbações, e por isso prefeririam extirpar a insistente possibilidade. É em relação a essa possibilidade presente, ou, mais concretamente, da possibilidade de uma música diferente e oposta que propriamente se regride". ${ }^{8} \mathrm{O}$ que naquele ensaio sobre a música se dizia de uma prática social específica aplica-se, na $D E$, aos fundamentos mesmos do modo de pensar próprio aos limites da razão esclarecida. E essa regressão manifesta-se naquilo que um jogo de palavras muito preciso designa por "juízo sem juízo". Manifesta-se em um modo de julgamento em que se fechou todo o espaço para a "ponderação", para a reflexão que permite descolar o predicado do sujeito a que se aplica, sem fazer de um o prolongamento direto, "brutal", do outro, sem amalgamá-los no estereótipo.

Entretanto, algo fundamental ocorreu nesse processo. Num momento tínhamos o comportamento anti-semita como a expressão paradigmática de pseudo-sujeitos agindo como ainda se o fossem, mas desatados de toda reflexão, à solta. Agora, o que se encontra desatado não é mais da ordem do sujeito, por débil que seja a sua subjetividade. É da ordem do objeto, e de um objeto historicamente bem determinado: os grandes conglomerados empresariais, os "colossos da produção". É como se efetivamente se consumasse a ironia da razão esclarecida, na qual tudo se orientava para o inteiro domínio do sujeito racional sobre a natureza como objeto submetido, para acabar por se desenvolver no sentido de uma espécie de "retorno do reprimido" na sua exacerbação mais patológica. Assim, a possível aproximação do objeto pelo sujeito de uma razão reflexiva realiza-se como o seu contrário, na absorção forçada do sujeito pelo objeto. $\mathrm{E}$ este faz o sujeito pagar com a sua aniquilação a sua incapacidade de sair da trajetória que ele mesmo soberanamente desenhara. Portanto, se não há mais anti-semitas é porque não há nem mais o simulacro de sujeitos. Certamente os "colossos da produção" não têm como assumir esse papel, pelo contrário: o que agora temos à solta não são mais débeis forças subjetivas, mas poderosas forças objetivas. $O$ anti-semitismo na sua versão mais viru-

8 Adorno, Th. W. "O fetichismo na música e a regressão da audição". Coleção "Os Pensadores", n.o 48. São Paulo, Abril Cultural, 1975, p. 188. Nesta citação e, especialmente, na próxima, a tradução não coincide com a coleção "Os Pensadores". É que aqui está sendo usada a versão original de 1938, que foi revista por Adorno na reedição do texto em 1963, atenuando as passagens de tom mais "radical", mas mantendo a essência do argumento. 
lenta não tem mais espaço. Os seus elementos no plano da conduta - a estereotipia, a personalização - deslocam-se para outras dimensões da vida social e se reorganizam no âmbito muito mais geral do ticketthinking. $\mathrm{O}$ anti-semitismo como um todo passa a ser um ticket entre outros, desprovido de valorização social específica. A dinâmica agora é outra, e dispensa a simulação de sujeitos. A energia consumida na canalização de impulsos específicos para o plano subjetivo é melhor mobilizada no enquadramento geral em padrões de pensamento e de conduta com claro respaldo objetivo.

\section{DESESPERO E SUPERAÇÃO}

Na passagem da forma de comportamento anti-semita à mentalidade do ticket, do pensar em bloco, ocorre um deslocamento fundamental. "Não é só o ticket anti-semita que é anti-semita, mas a mentalidade do ticket em geral". O que resta, então, para caracterizar o anti-semitismo? Na realidade, ele se dilui em algo muito mais geral: a "raiva feroz pela diferença", que é intrínseca à mentalidade do ticket. Aqui a inversão da relação sujeito/objeto na dialética da razão esclarecida ( trata-se de "sujeitos dominados da dominação da natureza") se traduz num "ressentimento" que aciona a prontidão contra a "minoria natural" facilmente identificável. De pouco vale, nessas circunstâncias, recorrer a um ticket de conteúdo progressista, capaz de atrair os "indivíduos psicologicamente mais humanos". No final, prevalece o descompasso entre o conteúdo humano e a forma intrinsecamente inumana. Na mentalidade do ticket a razão esclarecida de fato encontra seu limite. Põe-se, então, o problema da sua superação. Neste ponto os autores recorrem a um argumento que reaparece em outros textos (Adorno o usa para falar do império da ideologia sobre os homens) e que se assemelha curiosamente a certos argumentos da velha socialdemocracia no debate sobre as possibilidades do socialismo. A idéia básica é que tudo está objetivamente dado para dar-se o passo decisivo, o único pequeno passo que falta para a mudança, e o mais difícil de todos. $\mathrm{Na}$ realidade, para além dessa semelhança externa, encontra-se neste ponto um tema importante nos autores, especialmente em Adorno: o de que o pensamento não pode deter-se diante do dado, mas deve aprofundar-se nele até o ponto em que deixe de ser um dado sem mais e tenha sido apropriado pelo sujeito reflexivamente (ou seja, passando pela negação). No circuito fechado do anti-semitismo isso não se dá. "Ao invés de prosse- 
guir, penetrando na coisa, o pensamento inteiro se põe desesperadamente a serviço do juízo particular" ( $D E, 181)$. A alusão ao desespero tem função precisa no argumento. É que ofuscação não significa cegueira plena, ou ingenuidade. No fundo o sujeito vislumbra algo além do dado, mas não tem como atingi-lo. É nesses termos que os autores sustentam, já na fase conclusiva do texto, que por detrás da mentira anti-semita lateja a verdade, da qual "os destituídos do poder de julgar só podem ser separados pela perda total do pensamento" ( $D E, 194)$. Fica implícita a sugestão de que isso é impossível, de que aqui se desenham os limites, não mais do Esclarecimento mas da ofuscação que o constrange. Isto permite dar a palavra final nesse texto sombrio à capacidade da razão de superar seus próprios limites. "O próprio Esclarecimento, em plena posse de si mesmo e transformando-se em violência, conseguiria romper os limites do Esclarecimento".

Que fazer com essa conclusão? Alguns se sentiriam inclinados a ver nela um desses morceaux de bravure de que Adorno, mais do que Horkheimer, nem sempre conseguia escapar. No entanto é forçoso reconhecer que ela resulta com inteira coerência do conjunto do texto. Nada há fora da razão que possa levá-la para além dos seus próprios limites históricos. Tudo depende da sua capacidade de tornar-se senhora de si, de não mais ficar à mercê dos caprichos do seu objeto naturalizado. Mas isto implica o mais difícil, a presença ativa de sujeitos senhores de si. A violência de que se fala aqui tanto pode significar a violência histórica, a força revolucionária, quanto, num registro mais "superestrutural" bem ao gosto dos autores especialmente de Adorno, a violência mais sutil da ruptura, do breakthrough, do ir além dos próprios limites. Os autores falam do modo desesperado como os sujeitos ainda ofuscados se agarram ao logro que lhes é imposto por um ticket de conteúdo praticamente nulo e que eles acabam perpetuando. Também neste ponto a referência ao desespero é importante. A adesão às condições dadas por sujeitos prejudicados, que delas nada podem esperar, tanto pode resultar na reprodução do ressentimento de quem no fundo sabe do logro mas não sabe por onde atacá-lo quanto no gesto, quase imperceptível mas de violênçia máxima, que rompe o véu. É como se no momento da sua plena aniquilação por uma objetividade esmagadora os sujeitos pudessem perceber que o mesmo peso que os oprime também reduziu a quase nada a fonte do seu ofuscamento. Mas a violência de que se fala é também material, embora não revolucionária. Consiste em impor limites, e limites humanos e não só técnico-administrativos, aos "colossos da produção" desatados. Aqui o círculo se fecha, mas a idéia é justamente que ele não pode se fechar. $\mathrm{Na}$ 
realidade a questão não está em fechar o círculo mas em rompê-lo de vez. Para isso importa o hiato que se forma entre as duas dimensões em que nos limites da razão esclarecida se põe a condição de estar "à solta", de estar "desatado": nos pseudo-sujeitos privados de reflexão ou então nos "colossos da produção". Estes últimos não estão desatados por carência de uma faculdade interna, como seria a capacidade racional reflexiva no plano individual. Nada lhes foi tirado. Pelo contrário, expandem-se desenfredamente. Só podem ser contidos na sua marcha frenética a partir de fora - pela ação de sujeitos senhores de si, portanto. A desgraça histórica está na passagem linear de um "desatar-se" ao outro, sem que interfira o momento reflexivo no primeiro. Não se trata portanto de fechar o hiato mas de escancará-lo. Admitamos que é uma situação difícil. Como diria em outro momento Adorno, citando um epigrama polonês: "Abre-te Sésamo, quero sair".

\section{IMPASSE E NOVAS CONDIÇÕES}

Tudo indica que para Adorno e Horkheimer o momento histórico em que viviam era marcado por um impasse. Meio século depois, continua o impasse? É da mesma natureza? Há soluções à vista ou, no melhor estilo frankfurtiano, num ponto de fuga no horizonte? Essas questões remetem a uma outra, mais funda, sobre o que para eles mantém coesa essa sociedade que dispensa o modo de comportamento anti-semita, não para superá-lo historicamente mas para reproduzir o que ele tem de essencial (a incapacidade de ver o outro com olhos abertos) no interior de algo que transcende as formas de conduta e se traduz numa forma de pensar, numa mentalidade. Neste ponto ganha inteiro sentido a menção de Adorno ao processo de reificação, no estudo sobre a personalidade autoritária. Ao escrever aquele texto Adorno tinha mais referências do que as que se manifestam nas suas contribuições à Dialética do Esclarecimento. Uma delas já foi mencionada antes. Trata-se do ensaio sobre o fetichismo na música. Nele Adorno levanta a questão da fonte da coesão da sociedade burguesa na época do capital monopolista, e a localiza na dinâmica superestrutural. "Também no âmbito da superestrutura a aparência não é apenas o ocultamento da essência mas resulta imperiosamente da própria essência", sustenta. Vale a pena lembrar aqui o modo como naquele artigo Adorno busca dar conta do processo social mais amplo que permite explicar o fetichismo e a regressão auditiva na música. "Nas condições de dis- 
solução da economia burguesa, quanto mais inexoravelmente o princípio do valor de troca burla as pessoas no prazer dos valores de uso, tanto mais o próprio valor de troca disfarça-se em objeto de prazer. Tem-se perguntado sobre o cimento que ainda mantém coesa a sociedade da mercadoria, quando já se consumou o seu julgamento econômico. Para a explicação disso pode contribuir a transferência do prazer do valor de uso dos bens de consumo para o seu valor de troca, no interior de uma constituição global na qual finalmente todo o prazer que se emancipe do valor de troca assume traços subversivos. $\mathrm{O}$ aparecimento do valor de troca nas mercadorias assumiu função específica de cimento social". Isto conduz a uma consideração de interesse imediato no presente contexto: "No fetichista da mercadoria de novo estilo, no 'caráter sadomasoquista' e no consumidor da arte de massa atual a mesma coisa apresenta-se por faces diferentes. A cultura de massa masoquista é a aparência necessária da própria produção: da produção monopolista". No texto sobre o anti-semitismo da Dialética do Esclarecimento isto tem a sua primeira contrapartida na tese de que "o anti-semitismo burguês tem um fundamento econômico específico: o disfarce da dominação na produção". Em consequiência disso, toda a carga socialmente visível da exploração é descarregada na esfera da circulação, cujos ocupantes mais expostos são os judeus. Mas isto não esgota a questão, pois se refere a um momento já superado do processo capitalista, à sua fase mais propriamente concorrencial. Na fase monopolista a dinâmica é outra. Já não se trata de soltar pseudo-sujeitos contra bodes expiatórios, mas de assegurar a coesão da sociedade por meios menos pontuais e mais seguros. Ao invés de dar a ilusão da iniciativa a indivíduos ofuscados desloca-se toda a iniciativa para o polo objetivo, da produção material e simbólica organizada em grandes conglomerados empresariais.

Muito do que se possa dizer da relevância contemporânea das análises de Adorno e Horkheimer e dos ajustes que as novas condições do mundo thes imporiam passa por uma questão simples: os colossos econômicos continuam desatados? Ou, em outros termos: a base material para o ticket-thinking persiste, ou está superada, ou se consolidou em novos termos? Alguns temas são de evidente interesse nessa discussão. Em primeiro lugar seria possível ponderar que as referências de ambos os autores à organização econômica e, sobretudo, à organização do trabalho ainda estão inteiramente presas ao chamado "modelo fordista" (por exemplo, na relação que estabelecem entre produção em série e estereotipia), e que as formas emergentes de reorganização dos processos produtivos trazem a perspectiva de graus de flexibilidade e autonomia individual impensáveis há 50 anos. 
Claro que a isto se oporá que se trata de tendências sem qualquer capacidade de expansão no interior das sociedades, e se chegará ao tema da "exclusão social". Por outro lado, será invocado o desenvolvimento das indústrias da comunicação e da informação, igualmente impensável em meados do século. Com relação a isso certamente se falará do aumento de mobilidade, de interatividade e, afinal, de autonomia dos indivíduos nas "redes comunicacionais informáticas" naquilo que, num registro crítico, já foi denominado "idade mídia" 9 A isso se responderá que na realidade estamos diante de refinamentos do que já fora diagnosticado em suas tendências básicas na parte sobre "indústria cultural" da Dialética do Esclarecimento. Em nenhum desses casos haverá condições para demonstrar que os grandes conglomerados empresariais estejam hoje significativamente mais sob o controle de uma cidadania formada por sujeitos autônomos de uma razão reflexiva do que era o caso quando foi escrita a Dialética do Esclarecimento. Parece também ser recomendável muita cautela na afirmação de que o ticket-thinking tenha deixado de ser a forma dominante da mentalidade nas sociedades contemporâneas. Isto vale especialmente para a ênfase atual na expansão de mecanismos de escolha em sociedades altamente complexas, informatizadas, inscritas em fluxos globais. Neste ponto a questão é de saber se essas novas condições neutralizam a observação na Dialética do Esclarecimento citada antes, de que na presença dos grandes conglomerados econômicos e na vigência do ticket-thinking "continua-se a escolher, mas apenas entre totalidades".

Mas com certeza seria surpreendente se meio século de produção intensiva nas ciências sociais não tivessem registrado mudanças na organização e nas tendências das sociedades capazes de promover um reexame das teses frankfurtianas, nem tivessem um nível de elaboração teórica capaz de gerar novas interrogações e novas teses. Talvez um bom caminho para enfrentar as questões de Adorno e Horkheimer nos termos contemporâneos seja dado pelos autores europeus (como Beck, Giddens e Lasch, para citar os três que produziram a mais difundida obra de síntese a respeito ${ }^{10}$ ) que in-

\footnotetext{
9 Antonio Albino Canelas Rubim (org.) Idade Midia. Salvador, Editora da Universidade Federal da Bahia/EDUFBA, 1995. Esta referência permite lembrar as interessantes contribuições para o debate nessa área que vêm sendo feitas pela equipe de pesquisadores da Faculdade de Comunicação da UFBA e em outros centros de pesquisa brasileiros, como o Centro de Pesquisas em Novas Tecnologias, Comunicação e Cultura coordenado por Ciro Marcondes Filho na ECA/USP.

10 Beck, Ulrich, Anthony Giddens \& Scott Lash. Reflexive Modernization. Politics, Tradition and Aesthetics in the Modern Social Order. Cambridge. Polity Press/Stanford. University of Stanford Press, 1994.
} 
troduziram no debate temas como os da "sociedade de risco" e da "modernização reflexiva". Aqui chegamos a um ponto crucial de contato entre as análises de Adorno e Hokheimer e vertentes contemporâneas. E a palavra-chave, claro, é "reflexividade". Nessas análises, que em alguns pontos exibem referências ao tema da dialética do esclarecimento, a tese é precisamente que, nas novas condições de percepção de que os riscos "naturais" são crescentemente produzidos pelo homem e de expansão do cuidado com a relação sociedade/ambiente, tende a desenvolver-se um novo padrão de organização social, marcado precisamente pela reflexividade que as teses da Dialética do Esclarecimento viam em declínio. Seria demais esperar que análises desse tipo apontassem para algo além da razão esclarecida cujos limites Adorno e Horkheimer buscavam diagnosticar. Mas no mínimo envolvem a idéia de que esses limites são mais elásticos do que os a teoria crítica da sociedade de matriz frankfurtiano supunha. Ou então, para voltarmos ao registro do presente texto, podem levar à constatação de que o ticketthinking está arraigado mais fundo e com maior eficácia do que nunca.

Não há conclusão substantiva para este artigo. Há uma convicção, a ser explicitada. Quem ler, como cabe, a melhor produção do pensamento social contemporânea, incluindo a que trata das perspectivas da informatização e aquela dedicada ao tema da reflexibilidade social, sem reler essa obra-prima de meados do século que é a Dialética do Esclarecimento, perderá muito da riqueza das idéias sobre tendências sociais produzidas neste século. Correrá mesmo o risco de ficar enleado nos limites da razão esclarecida e de aceitar irrefletidamente algum ticket atraente do novo mercado global.

GABRIEL COHN é professor no Departamento de Ciência Política da FFLCH/USP. Na mesma área temática publicou, em Lua Nova n.o 20/1990, "Difícil reconciliação: Adorno e a dialética da cultura". 


\title{
RESUMOS/ABSTRACTS
}

\author{
ESCLARECIMENTO E OFUSCAÇÃO: \\ ADORNO \& HORKHEIMER HOJE
}

GABRIEL COHN

Passado meio século da publicação da Dialética do Esclarecimento de Horkheimer e Adorno, propõe-se uma reflexão sobre o significado dessa obra no seu momento e agora. Para isto sugere-se uma interpretação dos argumentos básicos da sua parte dedicada ao anti-semitismo, especialmente no que concerne à referência dos autores aos "limites do Esclarecimento".

\section{ENLIGHTENMENT AND VERBLENDUNG: ADORNO \& HORKHEIMER TODAY}

Half a century after the publication of Horkheimer and Adorno's Dialectics of Enlightenment a reflection is proposed about the meaning of this work at its moment and today. In order to do this an interpretation of the basic arguments of its section on antisemitism is put forward, especially regarding the authors' reference to the "limits of Enlightenment". 